\title{
Ex vitro acclimatization of Hippeastrum reticulatum (Amaryllidaceae) using different substrates
}

\author{
Willian Heintze ${ }^{1}$ \\ Gilmar Schafer ${ }^{1}$ \\ Marília Milani $^{1} \odot$ Elisandra Maria Pradella $^{2} \odot$ Claudimar Sidnei Fior $^{1} \odot$
}

${ }^{1}$ Departamento de Horticultura e Silvicultura, Programa de Pós Graduação em Fitotecnia, Faculdade de Agronomia, Universidade Federal do Rio Grande do Sul (UFRGS), 91540-000, Porto Alegre, RS, Brasil. E-mail: willianpr@gmail.com. " Corresponding author. ${ }^{2}$ Departamento de Horticultura e Silvicultura, Universidade Federal do Rio Grande do Sul (UFRGS), Porto Alegre, RS, Brasil.

ABSTRACT: Hippeastrum spp. are herbaceous species belonging to the family Amaryllidaceae, widely marketed worldwide as indoor plants. Aiming to characterize chemically and physically and to compare five substrates in acclimatization, micropropagated seedlings of Hippeastrum reticulatum var. striatifolium (Herb), with an average of four roots, two leaves and bulbs with a $4.7 \mathrm{~mm}$ diameter, were transplanted to 50-cell polyethylene trays each containing the following substrates: T1 - vermiculite, T2 - carbonized rice husk (CRH), T3 - commercial (peat + vermiculite + CRH), T4 - coconut fiber, and T5 - composted Pinus bark. After transplantation, the trays were kept for 17 days at a greenhouse with intermittent irrigation by nebulization, and 80 days at a greenhouse on a bench with intermittent irrigation by capillarity. The experimental design was randomized blocks with seven replications and ten seedlings per plot. The acclimatization of seedlings was efficient for the substrates tested despite the differences verified by chemical and physical characterization. The mean survival rate was $96 \%$. However, seedlings acclimatized in the T5 substrate showed a qualitative improvement due to a higher formation of roots, leaves and fresh matter. Key words: micropropagation, seedling production, floriculture.

\section{Aclimatização ex vitro de Hippeastrum reticulatum (Amaryllidaceae) em diferentes substratos}

RESUMO: Hippeastrum spp. são espécies herbáceas pertencentes à família Amaryllidaceae, muito comercializadas mundialmente como plantas envasadas para ambientes de interior. Objetivando caracterizar química e fisicamente, e comparar cinco substratos na aclimatização, mudas micropropagadas de Hippeastrum reticulatum var. striatifolium (Herb) Herb., com média de quatro raizes, duas folhas e bulbos com 4,7mm de diâmetro, foram transplantadas para bandejas de polietileno com 50 células de $50 \mathrm{~cm}^{3}$ cada, contendo os substratos: T1 - vermiculita; T2 - casca de arroz carbonizada (CAC); T3 - comercial (turfa+vermiculita+CAC); T4 - fibra de coco; e, T5 - casca de pinus compostada. Após o transplante as bandejas foram mantidas por 17 dias em casa de vegetação com irrigação intermitente por nebulização, e mais 80 dias em casa de vegetação sobre bancada com irrigação intermitente por capilaridade. O delineamento experimental foi o de blocos casualizados, com sete repetições e dez mudas por parcela. A aclimatização de mudas foi eficiente nos substratos testados, apesar das diferenças obtidas na caracterização química e física, com sobrevivência média de 96\%. No entanto, as mudas aclimatizadas no substrato T5 se destacaram qualitativamente, por apresentar maior formação de raizes, folhas e massa da matéria fresca.

Palavras-chave: micropropagação, produção de mudas, floricultura.

\section{INTRODUCTION}

Hippeastrum reticulatum var. striatifolium (Herb.) Herb. (Amaryllidaceae) is a bulbous species native to the Atlantic Forest. Presenting a great aesthetic beauty, it has persistent bright dark green leaves that contrast with a thick whitish midrib. It blooms once a year. Its occurrence is in late summer to early fall in the southern hemisphere. It emits a unique scape that may present from three to five pink flowers in the form of trumpets and pendants with an ephemeral duration (about a week). Flowering may last for a month due to a sequence of opening of each flower of a same scape. Although, it presents a great ornamental potential, this species is little known by the consumer market and there are no propagation studies in the literature.

Micropropagation allows the production of genetically homogeneous seedlings within a reduced time. Acclimatization is a critical step of this process (GRATTAPAGLIA \& MACHADO, 1990; SILVA et al., 2011). This stage consists of a gradual adaptation of seedlings of an in vitro environment to an ex vitro environment, controlling factors that may limit or stop the development of plants, such as temperature, luminosity, substrate, nutrients and, mainly, moisture. Intermittent nebulization systems are used to keep a high relative humidity inside the acclimatization environment (GRATTAPAGLIA \& MACHADO, 1990). 
The substrate is also a critical issue for the transplanting of micropropagated seedlings. It should have a good capacity of humidity retention without compromising the aeration of the root system, and should be chemically inert to allow nutritional manipulation according to species (GRATTAPAGLIA \& MACHADO, 1990; CALVETE et al., 2000). Among the physical characteristics, we mentioned density, porosity and available water and air (KÄMPF, 2005). The most important chemical characteristics in the substrates are $\mathrm{pH}$ value and electrical conductivity. This study aims to characterize and compare different substrates in the acclimatization of seedlings of Hippeastrum reticulatum var. striatifolium (Herb.) Herb.

\section{MATERIALS AND METHODS}

Micropropagated seedlings with a mean of four roots and two leaves (approximately $3.25 \mathrm{~cm}$ each root, and $2.10 \mathrm{~cm}$ each leaf) and bulbs with a $4.7 \mathrm{~mm}$ diameter were transplanted to 50 -cells polyethylene trays of $50 \mathrm{~cm}^{3}$ each containing each the following substrates: T1: expanded vermiculite, T2: carbonized rice husk (CRH), T3: commercial 1 (according to specifications on the label, composed of Sphagno peat, expanded vermiculite, $\mathrm{CRH}$, dolomitic limestone, gypsum and NPK fertilizer), T4: coconut fiber, and T5: composted Pinus bark.

The physical and chemical analysis of the substrates was performed at the Laboratory of Analysis of Substrates for Plants of the Faculty of Agronomy, Universidade Federal do Rio Grande do Sul (UFRGS), according to HOFFMANN, 1970; DE BOODT \& VERDONCK, 1972 and BRAZIL, 2007. Physical parameters analyzed were wet bulk density $\left(\mathrm{D}_{\mathrm{W}}\right)$, dry bulk density $\left(\mathrm{D}_{\mathrm{D}}\right)$, total porosity (TP), air filled porosity (AFP), easily available water (EAW), buffer water (BW) and remaining water (RW). Chemical parameters evaluated were potential of hydrogen $(\mathrm{pH})$ determined in water at a dilution of 1:5 (v/v) and electrical conductivity (EC) obtained using a 1:5 (v/v) solution.

After the transplant, the trays were kept for 17 days at a greenhouse with intermittent irrigation by nebulization, in which the irrigation system was activated for 15 seconds every 5 minutes from 7 a.m. to 7 p.m., and for 15 seconds every 15 minutes, keeping an average air humidity $(\mathrm{RH})$ at $87.5 \%(\sigma 7.7 \%)$ and an average temperature at $24.9^{\circ} \mathrm{C}\left(\sigma 4.6^{\circ} \mathrm{C}\right)$. In the rest of the period ( 80 days), the trays were kept at a greenhouse at average $\mathrm{RH}$ conditions of $78.1 \%(\sigma$ $13.0 \%)$ and a mean temperature of $23.2^{\circ} \mathrm{C}\left(\sigma 5^{\circ} \mathrm{C}\right)$ using an intermittent capillary irrigation system for two minutes twice a day, so that the water formed a two-centimeter blade on the bench, gradually decreasing until completely drained by a hole located at the center of the bench, a process that lasted for approximately five minutes after system shutdown. The experimental design was randomized blocks with seven replications and ten seedlings per plot. After 97 days, plants were evaluated as for percentage of survival $(\% \mathrm{~S})$, number of roots (NR), sum of root length per seedling (SRL), sum of shoot diameter per seedling (SSD), mean of shoot diameter (MSD), number of leaves (NL) and sum of leaf length per shoot (SLLS), and fresh mass per seed (FMS). Each bulb was considered a shoot, since there were seedlings with more than one interconnected bulb. Length measurements were made using a ruler. Diameter measurements were made using a digital caliper. Mass measurements were made using an analytical balance. Data were subjected to analysis of variance and means were compared by Tukey test at $5 \%$ probability of error.

\section{RESULTS AND DISCUSSION}

In the case of acclimatization by nebulization, a substrate is desired that will rapidly drain excess water, i.e., with a high air filled porosity (AFP) (CALVETE et al., 2000). This was obtained in all treatments, except for T5, with an emphasis on T2 (Table 1). The AFP must be determined taking into account the location of the seedlings and the species to be acclimatized, avoiding extreme conditions (excess and lack of water in the substrate). When this is not satisfactory, there may be damages to seedlings due to excess of water and, consequently, root aeration deficiency, which in this irrigation system may lead to accumulation of water on trays. This was not observed in this experiment.

When transferring the trays to benches with an intermittent irrigation by capillarity, the ideal is the use of a substrate that stores a large volume of water easily available to plants. Its value is obtained by the sum of easily available water (EAW) with buffer water (BW) (KÄMPF, 2005). The T3 substrate presented the highest volume of available water (Table 1).

In order to allow an efficient gas exchange and avoid the lack of oxygen for root respiration (KÄMPF, 2005), the total porosity (TP) in an ideal substrate should be approximately $85 \%$ (DE BOODT \& VERDONCK, 1972). The T5 substrate was characterized by a TP below the ideal, while the other treatments were above (T1 to T3) or very close to the TP considered ideal (T4) (Table 1). 
Table 1 - Potential of hydrogen $(\mathrm{pH})$, electrical conductivity $(\mathrm{EC})$, wet bulk density $\left(\mathrm{D}_{\mathrm{W}}\right)$, dry bulk density $\left(\mathrm{D}_{\mathrm{D}}\right)$, total porosity $(\mathrm{TP})$, air filled porosity (AFP), easily available water (EAW), buffer water (BW) and remaining water (RW) from different substrates used for the acclimatization of Hippeastrum reticulatum var. striatifolium seedlings. Laboratory of Analysis of Substrates, Department of Horticulture and Forestry, Faculty of Agronomy, Universidade Federal Do Rio Grande do Sul (UFRGS), Porto Alegre, 2012.

\begin{tabular}{|c|c|c|c|c|c|c|}
\hline & & - & ---------. & eatments & ---------. & 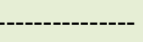 \\
\hline ------. & inations------ & $\mathrm{T} 1^{*}$ & $\mathrm{~T} 2$ & $\mathrm{~T} 3$ & $\mathrm{~T} 4$ & $\mathrm{~T} 5$ \\
\hline $\mathrm{pH}$ & $\mathrm{H}_{2} \mathrm{O}$ & 5.84 & 6.73 & 5.51 & 5.72 & 5.29 \\
\hline $\mathrm{EC}$ & $\mathrm{mS} \mathrm{cm}-1$ & 0.12 & 0.08 & 0.81 & 0.19 & 0.16 \\
\hline $\mathrm{D}_{\mathrm{W}}$ & $\mathrm{kg} \mathrm{m}^{-3}$ & 473.60 & 216.97 & 304.83 & 132.17 & 580.60 \\
\hline $\mathrm{D}_{\mathrm{D}}$ & $\mathrm{kg} \mathrm{m}^{-3}$ & 162.03 & 139.56 & 153.74 & 69.75 & 465.22 \\
\hline TP & $\%$ & 93.12 & 85.42 & 88.35 & 83.55 & 54.92 \\
\hline AFP & $\%$ & 39.79 & 62.50 & 35.32 & 44.78 & 12.76 \\
\hline EAW & $\%$ & 8.83 & 12.52 & 20.42 & 12.34 & 10.15 \\
\hline BW & $\%$ & 2.42 & 0.84 & 3.27 & 1.13 & 1.57 \\
\hline RW & $\%$ & 42.08 & 9.56 & 29.33 & 25.30 & 30.44 \\
\hline
\end{tabular}

*T1 - vermiculite, T2 - carbonized rice husk (CRH), T3 - commercial (peat + vermiculite + CRH), T4 - coconut fiber $(\mathrm{CF})$, and $\mathrm{T} 5$ composted Pinus bark (CPB).

In relation to $\mathrm{pH}$, only the $\mathrm{T} 2$ substrate presented a marked value above the recommended (5.0-5.8) (KÄMPF, 2005; WILKERSON, 2018) (Table 1), but this substrate has little buffering power, and $\mathrm{pH}$ is not a limiting factor in this case.

Only the T3 substrate presented values of electrical conductivity (EC) above the upper limit of EC range considered normal for most established plants. However, it was high for sensitive plants $\left(0.65 \mathrm{mS} \mathrm{cm}^{-1}\right)$ (Table 1) when determined by the method 1:5 discussed by CAVINS et al. (2000). Very high EC values in acclimatization may cause seedling mortality.

The survival of seedlings did not differ between substrates, being above 96\%. Because the species studied is bulbous, it contributes to the homogeneity of seedlings among treatments, keeping the plant nourished at the expense of bulb reserves even when the substrate does not provide all the nutrients required. This reflects mainly in the number of seedlings surviving the acclimatization process. There were no significant differences among substrates as for sum of shoot diameter per seedling (SSD). The sum of bulb diameter of each seedling was $11.33 \mathrm{~mm}$. Plants cultivated in the T2 substrate had the smallest average shoot diameter (MSD) (8.1, not differing from vermiculite). The T5 substrate provided the highest values for number of roots (NR) (5.5, not differing from $\mathrm{T} 1, \mathrm{~T} 3$ and $\mathrm{T} 4$ ), sum of root length (SRL) $(56.5 \mathrm{~cm})$, number of leaves per shoot (NL) (2.5, not differing from T1), sum of leaf length (SLLS) $(17.60 \mathrm{~cm}$, not differing from T1, T2 and T3), and fresh matter per seed (FMS) (2.16 g) (Table 2). Although, the T5 substrate has a total porosity below the ideal, seedlings developed very well in this substrate during acclimatization.

The T2 substrate presented negative results for several variables related to seedling growth. This negative development may also be related to the fact that $\mathrm{T} 2$ is an inert substrate, presenting the lowest absolute mean for electrical conductivity, a factor that could be manipulated by fertigation, improving the growth of seedlings after an initial adaptation ex vitro (beginning of acclimatization). The T2 substrate also had a high air filled porosity (AFP) in relation to the other treatments evaluated, a factor considered negative by CALVETE et al. (2000), who observed that strawberry seedlings growing in a substrate with high AFP values presented low results for all evaluated parameters. Although, a high AFP is desired for acclimatization substrates, this factor may adversely interfere with water availability, especially when the plant is removed from an environment irrigated by intermittent nebulization. 
Table 2 - Percentage of survival to acclimatization (\%S), sum of shoot diameter per seedling (SSD), mean of shoot diameter (MSD), number (NR) and sum of root length per seedling (SRL), and number (NL) and sum of leaf length per shoot (SLLS), and fresh mass per seedling (FMS) of Hippeastrum reticulatum var. striatifolium acclimatized using different substrates.

\begin{tabular}{|c|c|c|c|c|c|c|c|c|}
\hline Substrate & $\begin{array}{l}\% \mathrm{~S} \\
(\%)\end{array}$ & $\begin{array}{l}\text { SSD } \\
(\mathrm{mm})\end{array}$ & $\begin{array}{l}\text { MSD } \\
(\mathrm{mm})\end{array}$ & NR & $\begin{array}{l}\text { SRL } \\
(\mathrm{cm})\end{array}$ & NL & $\begin{array}{c}\text { SLLS } \\
(\mathrm{cm})\end{array}$ & $\begin{array}{c}\text { FMS } \\
(\mathrm{g})\end{array}$ \\
\hline $\mathrm{T} 1$ & $95.7^{\mathrm{ns}}$ & $11.10^{\mathrm{ns}}$ & $8.36 \mathrm{ab}^{*}$ & $5.2 \mathrm{ab}$ & $47.8 \mathrm{~b}$ & $2.4 \mathrm{ab}$ & $15.8 \mathrm{ab}$ & $1.67 \mathrm{~b}$ \\
\hline $\mathrm{T} 2$ & 98.6 & 12.18 & $8.10 \mathrm{~b}$ & $5.0 \mathrm{~b}$ & $47.6 \mathrm{~b}$ & $2.2 \mathrm{bc}$ & $15.5 \mathrm{ab}$ & $1.74 \mathrm{~b}$ \\
\hline $\mathrm{T} 3$ & 95.7 & 10.88 & $8.86 \mathrm{a}$ & $5.2 \mathrm{ab}$ & $47.3 \mathrm{~b}$ & $2.3 \mathrm{~b}$ & $16.2 \mathrm{ab}$ & $1.73 \mathrm{~b}$ \\
\hline $\mathrm{T} 4$ & 92.9 & 10.54 & $8.78 \mathrm{a}$ & $5.2 \mathrm{ab}$ & $46.3 \mathrm{~b}$ & $2.1 \mathrm{c}$ & $14.6 \mathrm{~b}$ & $1.59 \mathrm{~b}$ \\
\hline $\mathrm{T} 5$ & 97.1 & 11.94 & $8.93 \mathrm{a}$ & $5.5 \mathrm{a}$ & $56.5 \mathrm{a}$ & $2.5 \mathrm{a}$ & $17.6 \mathrm{a}$ & $2.16 \mathrm{a}$ \\
\hline Average & 96.0 & 11.33 & - & - & - & - & - & - \\
\hline CV (\%) & 6.84 & 15.13 & 8.48 & 12.55 & 15.23 & 8.81 & 12.79 & 19.80 \\
\hline
\end{tabular}

${ }^{n}$ : not significant. "Means followed by different letters in columns differ statistically by Tukey test at the 5\% probability of error. T1 - vermiculite, T2 - carbonized rice husk (CRH), T3 - commercial (peat + vermiculite + CRH), T4 - coconut fiber (CF), and T5 composted Pinus bark (CPB).

The acclimatization of micropropagated seedlings was efficient in all substrates, with a qualitative emphasis for T5, which presented excellent results. The number of roots was good in all treatments, as well as the quality of the root system. There were many long roots per seedling, making it necessary to prune the roots of all seedlings at the moment of transplanting them to pots after the evaluation of the experiment.

All substrates are available and are relatively easy to purchase. Cost may vary mainly in relation to freight. However, as at this phase of cultivation, the substrate requirement is low $\left(50 \mathrm{~cm}^{3}\right.$ per seedling). It does not exceed two cents per seedling ( $\mathrm{R} \$ 0.01$ to 0.02 ). Therefore, the factor cost should not be preponderant for the choice of a substrate. The substrate that provided the best vegetative development should drive the choice, in this case, T5. Coincidentally, regarding its source, $\mathrm{T} 5$ is one of the cheapest substrates.

\section{CONCLUSION}

All tested substrates were efficient for the acclimatization of micropropagated seedlings of Hippeastrum reticulatum. The use of composted Pinus bark provided seedlings with a greater mass and more leaves and roots.

\section{ACKNOWLEDGMENTS}

The authors would like to thank to the Conselho Nacional de Desenvolvimento Científico e Tecnológico (CNPq) and to the Fundação de Amparo à Pesquisa do Estado do Rio Grande do Sul (FAPERGS) for the financial support.

\section{DECLARATION OF CONFLICTING INTERESTS}

The authors declare no conflict of interest. The founding sponsors had no role in the design of the study; in the collection, analyses, or interpretation of data; in the writing of the manuscript, and in the decision to publish the results.

\section{AUTHORS' CONTRIBUTIONS}

All authors contributed equally for the conception and writing of the manuscript. All authors critically revised the manuscript and approved of the final version.

\section{REFERENCES}

BRASIL. Ministério da Agricultura, Pecuária e abastecimento (MAPA). Secretaria de Defesa Agropecuária (SDA). Instrução Normativa SDA No 17 de 21 de maio de 2007. Métodos Analíticos Oficiais para Análise de Substratos e Condicionadores de Solos. Diário Oficial da União, Brasília, DF, 24 de maio 2007. Available from: <http://extranet.agricultura.gov.br/sislegis-consulta/servlet/ VisualizarAnexo?id=14783>. Accessed: Nov. 03, 2018.

CALVETE, E.O. et al. Efeito do substrato na aclimatização ex vitro de morangueiro cv Campinas, Fragaria x ananassa Duch. In: KÄMPF, A.N.; FERMINO, M.H. (Ed.). Substrato para plantas: a base da produção vegetal em recipientes. Porto Alegre: Genesis, 2000. p.257-264.

CAVINS, T. J. et al. Monitoring and managing $\mathrm{pH}$ and EC using the PourThru extraction method. Horticulture Information Leaflet, North Carolina, v.590 p.1-17, 2000. Available from: <http://www. 
ncsu.edu/project/hortsublab/pdf/PourThru_Master_HIL.pdf $>$. Accessed: Nov. 03, 2018

DEBOODT,M;VERDONCK, O. The physical properties of the substrates in horticulture. Acta Horticulturae, Wageningen, v.26, p.37-44, 1972. Available from: <http://dx.doi.org/10.17660/ActaHortic.1972.26.5>. Accessed: Nov. 03, 2018. doi: 10.17660/ActaHortic.1972.26.5.

GRATTAPAGLIA, D.; MACHADO, M. A. Micropropagação. In: TORRES, A C.; CALDAS, L. S. (Ed.). Técnicas e aplicações da cultura de tecidos de plantas, Brasília, DF: ABCTP/Embrapa, 1990, p.99-170.

HOFFMANN, G. Verbindliche methoden zur untersuchung von TKS und gartnerischen erden. Mitteilungen der VSLUFA, Heft, v.6, p.129-153, 1970 .
KÄMPF, A. N. Produção comercial de plantas ornamentais. 2. ed. Guaíba: Agropecuária, 2005. 256p.

SILVA, A. L. L., et al. Pré-aclimatização e aclimatização em cultivo hidropônico de plantas micropropagadas de Eucalyptus saligna Sm. Revista Acadêmica: Ciências Agrárias e Ambientais, Curitiba, v.9, n.2, p.179-184, Apr./ Jun. 2011. Available from: $<$ https://periodicos.pucpr.br/index. $\mathrm{php} /$ cienciaanimal/article/view/11780>. Accessed: Nov. 03, 2018. doi: 10.7213/cienciaanimal.v9i2.11780.

WILKERSON, Don. Texas Greenhouse Management Handbook: Growing Media \& pH. Available from: <http:// aggie-horticulture.tamu.edu/ornamental/greenhouse-management/ growing-media-ph/>. Accessed: Nov. 03, 2018. 